\title{
Metaphysical Analysis of the Nutritional and Therapeutic Value of Baobab (Adansonia Digitata L.)
}

\author{
Habte TY*, and Krawinkel MB
}

Department of International Nutrition, Institute of Human Nutrition, Justus-Liebig-University Giessen, Giessen, Germany

${ }^{*}$ Corresponding author: Habte TY, Department of International Nutrition, Institute of Human Nutrition, Justus-Liebig-University Giessen, Giessen, Wilhelmstrasse 20, 35392 Giessen, Germany, Yohannes. E-Mail: Tsige-Yohannes.Habte@ernaehrung.uni-giessen.de

Citation: Habte TY, Krawinkel MB (2017) Metaphysical Analysis of the Nutritional and Therapeutic Value of Baobab (Adansonia Digitata L.). J Nutr Health Sci 5(1): 101. doi: 10.15744/2393-9060.5.101

Received Date: October 06, 2017 Accepted Date: January 04, 2018 Published Date: January 08, 2018

\begin{abstract}
Realistic assessment of the yield and nutritional value of baobab as well as the elucidation of its inhibitory action against oxidative stress were the targets of the study. An average baobab tree can yield $80 \mathrm{~kg}$ fruits, $14 \mathrm{~kg}$ pulp, $23 \mathrm{~kg}$ seeds and $130 \mathrm{~kg}$ leaves per year. Despite considerable variability, the leaves outstrip in mean Ca (1241 mg/100g dry sample), Fe (40mg/100g dry sample) and $\beta$-carotene $(135 \mu \mathrm{g} / 100 \mathrm{~g}$ dry sample) content. The pulp is unequaled in vitamin C $(238 \mathrm{mg} / 100 \mathrm{~g})$, and it is rich in Ca $(320 \mathrm{mg} / 100 \mathrm{~g})$ as well. The seeds are very high in $\mathrm{Mg}(377 \mathrm{mg} / 100 \mathrm{~g}$ dry sample). Baobab's richness in vitamin C, B-carotene, calcium and magnesium as well as in phenolic antioxidants $(1085 \mathrm{mg} / 100 \mathrm{~g}$ pulp), which is about 10 times the level in common rich sources (fruits and vegetables) endows it with higher potential of neutralizing the ROS (reactive oxygen species) that exceed natural antioxidants.
\end{abstract}

Keywords: Baobab botanical parts; Yield; Nutritional value; Antioxidant activity

\section{Introduction}

There are nine species of the genus Adansonia (the baobab tree); six of them are endemic to Madagascar, two to North West Australia and one, Adansonia digitata L is endogenous to arid and semi-arid areas of Africa [1]. Throughout this article baobab represents Adansonia digitata L, a multi-purpose tree mostly known for its nutritional and health values.

Baobab produces relatively large silvery green or brownish indehiscent fruit comprising outer hard shell, inner soft whitish powdery pulp embedding kidney shaped dark brown seeds, all bound together by thin light brown fibers [2]. The fruits hung down from the branches until they are picked by hand or hooked by long rods. Under dry condition, they can be preserved for months without spoilage because of their natural low moisture content (about 10\%). The fruit pulp is the part that is more commonly used in food preparation. Ripe fruit pulp is separated from the fiber and seeds by kneading in cold water. It can then be eaten fresh, added to gruels after cooking, ground and made to refreshing drink with a pleasing wine-gum flavor, or it can stimulate the fermentation of sugar cane juice in brewing beer [3]. The level of inclusion of the pulp to the daily diet most often lies in the range of 10-20\% (30).

One unique characteristic of the pulp in food preparation is the thickening of sauces and jams probably because of its relatively high pectin content [4]. It also serves in local diets as a seasoning and appetizer. In some West African countries, the emulsion that results during the separation of pulp from seeds and fiber with cold water is mixed with milk to form a fine drink. Fermented fruit pulp occasionally substitutes the cream of tartar in baking. The fruit pods can burn as biofuel and produce potash [5].

In many parts of sub-Sahara Africa particularly in the savanna regions, the leaves of baobab are part of the staple diet. The tender leaves are picked during the rainy season to make fresh salad dishes or to be cooked as spinach whereas at the end of the rain season, the leaves are harvested in mass, sun dried and stored as dry leaves or as fine powder [6]. A large proportion (56\%) of the harvested leaf in central and some West African countries contribute to the dry season diets [7]. The mature leaves are cooked either with some potash or they are ground to fine powder, made to soup or sauce, which are consumed with thick porridge made of millet, sorghum or maize.

The seeds are dark brown to reddish black in color with smooth seed coat. They are dehulled by boiling, rubbing by hand after cooling, sun drying and grinding. Seed kernels are widely eaten fresh, dry, or ground and cooked with other foodstuffs [8]. They 
can also be roasted and eaten as snack; or dried, ground and mixed with sauces or soups as a thickener; or fermented and used as a flavoring agent of various dishes [9]. The seeds consist of about $15 \%$ fat, which makes them good sources of cooking oil [1,10].

The use of the different parts of baobab in the diets of rural communities living in several sub-Saharan countries and its ethno medical values are of long history [11]. In addition, the acceptance of baobab fruit pulp as food ingredient by the US Food and Drug Administration and the European Union, could increase the regional and international awareness and consumption of the fruit $[12,13]$. However, baobabs' nutritional benefits in terms of satisfying nutrient requirement and health maintenance are still inconclusive because of the variability in reports $[1,3,11,14,15]$.

The purpose of this study is therefore to give a realistic and comprehensive picture of the stand of knowledge in the chemical composition of baobab, and to highlight the levels of its inclusion in a diet, the mechanisms by which it can counter balance nutrient deficiency, hinder oxidative stress and maintain health.

\section{Materials and Methods}

In order to prove baobab as a multipurpose nutritious and healthy food, its nutrient composition and antioxidant activity were targeted for investigation. For these purposes, relevant literature that has been documented since the last twenty years is reviewed.

Secondly, test of nutrient adequacy of staple diets in Africa and the level of baobab that could supplement or complement the daily diets is calculated.

Finally, the interference of baobab in the pathway of oxidative stress is sketched and its potential to maintain health is discussed.

\section{Results and Discussions}

The level of baobab production, its nutritional and therapeutic values are presented and discussed separately.

\section{The Levels of Production}

The baobab trees grow comfortably in areas where the annual temperature ranges between $20-30{ }^{\circ} \mathrm{C}$; they are tolerant to high temperature (up to $42^{\circ} \mathrm{C}$ ) and survive long spans of drought $[16,17]$. They are impressive huge trees with an average mature height of $25 \mathrm{~m}$ and with crown diameter of $20 \mathrm{~m}$ [16]. Information about their fruit yield is scanty; an average of 380 units/tree/year with a range of 145-585 is reported for samples from the Sudan [18]. A lower average (360 units) with a wider range (12-1800 units) is recorded for the yield in Kenia (Eastern border counties); the consumption of immature fruits by wild animals could influence the accuracy of fruit yield [19].

In terms of gravimeter, the potential fruit yield of an average baobab tree is estimated at 200kg/year [20]. However, only $40 \%$ of the trees yield every year because of environmental influences and the failure of some trees to set fruit every season. Environmental attributes such as high levels of rainfall, relative humidity, temperature, evapotranspiration, $\mathrm{pH}$ of water, and percentage of fine silt are associated with low fruit pulp and seed production $[11,18,19]$. As a result annual fruit yield of $80 \mathrm{~kg} /$ tree is more realistic [20].

The average proportion of pulp in the fruit is $17.5 \%$, meaning $14 \mathrm{~kg}$ pulp production/tree/year. The fraction of seed in the fruit is $29.2 \%$ giving $23.4 \mathrm{~kg} /$ tree/season [11]. Information on the yield of leaves is limited; however, evidences from Mali show an average level of harvest equivalent to $130 \mathrm{~kg}$ leaf/tree/year [20].

\section{Nutritional Value}

The nutrient composition of baobab has been analyzed by different investigators and the results are summarized earlier by Chadare et al. (2008) [10], later by Rahul J et al. 2015 [8] and by others Table 1. In general, two observations are outstanding; first, the concentration of each nutrient is highly variable between and within similar biological parts of A. digitata. Secondly, despite extreme variations, baobab outstrips in calcium, vitamin C, iron and magnesium all other common foodstuffs denoted for their richness in these nutrients (Table 1 and 2).

The differences within the same botanical parts are largely attributed to genetic variety, followed by the influence of climate, soils type, post-harvest treatment, dry matter fluctuation, extraction methods and the method of chemical analysis [3,10].

Some evidence shows that the highest level of vitamin C $(575 \mathrm{mg} / 100 \mathrm{~g})$ was in the pulp coming from the regions with the lowest precipitation (450mm/year) [14]. Basic soils rich in organic matter, clay and fine silt positively correlate with the concentration of iron, zinc and vitamin $\mathrm{C}$ in the baobab, but not with that of calcium and magnesium, which accumulate to higher extent in the baobab trees growing in gross silt and sandy soils [10]. The type of leaves, age of tree (young or old), size of leaves (small or big), type of dehydration (sun- or shade dried), and the time-temperature combination in the procedure of absolute drying and ashing of samples, influence the nutrient concentration [9].

Sample collection (freedom from adulterates) storage (time and condition), preparation (drying and grinding), extraction and analytical spectroscopic procedures and accompanying materials count to the causes of variation in the results. Among the spectroscopic tools, the atomic absorption spectroscopy is relatively lower in sensitivity and precision than atomic emission 
spectroscopy, especially than that of ICP-OES-(Inductive Coupled Plasma Optic Emission Spectroscopy) [21]. In addition, the condition of their internal devices (e.g. incorrect lamp, misalignment of burner, blockage of nebulizer, as well as the sources and intensity of the energy (e.g. incorrect flame type, lamp current, blockage of burner) that agitate the atoms can influence the accuracy of results [21].

\begin{tabular}{|c|c|c|c|c|c|c|c|c|}
\hline Parts & $\mathrm{DM}(\mathrm{g} / \mathbf{1 0 0 \mathrm { g } )}$ & $\underset{(\mathrm{mg} / 100 \mathrm{~g})}{\mathrm{Ca}}$ & $\underset{(\mathrm{mg} / 100 \mathrm{~g})}{\mathrm{Mg}}$ & $\begin{array}{c}\mathrm{Fe} \\
(\mathrm{mg} / 100 \mathrm{~g})\end{array}$ & $\begin{array}{c}\mathrm{Zn} \\
(\mathrm{mg} / 100 \mathrm{~g})\end{array}$ & $\begin{array}{l}\text { Vitamin C } \\
(\mathrm{mg} / 100 \mathrm{~g})\end{array}$ & $\begin{array}{c}\text { B-carotene } \\
(\mu \mathrm{g} / 100 \mathrm{~g})\end{array}$ & Source \\
\hline \multirow{6}{*}{ Leaves } & 92 & 1582 & 339 & 65 & 4 & & 135 & \multirow{2}{*}{$\begin{array}{l}\text { Chadare et } \\
\text { al. 2008[10] }\end{array}$} \\
\hline & 91-93 & $307-2640$ & $93-549$ & $12-254$ & $0.7-22$ & & $107-156$ & \\
\hline & 91.8 & 1.5 & 2.5 & & & & & \multirow{2}{*}{$\begin{array}{l}\text { Abioye et al. } \\
2014^{*} \text { [22] }\end{array}$} \\
\hline & 90-94 & $0.8-1.5$ & $1.5-3.7$ & & & & & \\
\hline & 272 & 46 & & & & & 103 & \multirow{2}{*}{$\begin{array}{c}\text { Bamali et al. } \\
2014 \text { [1] }\end{array}$} \\
\hline & $200-315$ & $31-55$ & & & & & 54-157 & \\
\hline \multirow{11}{*}{ Pulp } & 88 & 302 & 195 & 4 & 1.7 & 290 & & \multirow{2}{*}{$\begin{array}{l}\text { Chadare et } \\
\text { al. } 2008\end{array}$} \\
\hline & $73-98$ & 3-701 & $100-300$ & $1.1-10.4$ & $0.5-3.2$ & $209-360$ & & \\
\hline & 88 & 317 & 148 & 6 & 0.8 & 108 & & \multirow{2}{*}{$\begin{array}{l}\text { LFR } 2009 \\
\quad[23]\end{array}$} \\
\hline & & $257-370$ & $126-179$ & $4-9$ & $0.7-1.0$ & $74-163$ & & \\
\hline & 90 & 345 & 199 & 10 & & 67 & & $\begin{array}{l}\text { Cissé I et al. } \\
\text { 2013[24] }\end{array}$ \\
\hline & & 293 & & & & 280 & & $\begin{array}{l}\text { Rahul et al. } \\
2015 \text { [8] }\end{array}$ \\
\hline & & 341 & 209 & 1.7 & 1.04 & 337 & & $\begin{array}{c}\text { Bamali et al. } \\
2014\end{array}$ \\
\hline & & 313 & 152 & 6.5 & 0.89 & & & \multirow{2}{*}{ LFR 2009} \\
\hline & & $257-370$ & 126-179 & $3.9-9.1$ & $3.9-9.1$ & 108 & & \\
\hline & & & & & & 478 & & \multirow{2}{*}{$\begin{array}{l}\text { Parkouda et } \\
\text { al. } 2011 \text { [14] }\end{array}$} \\
\hline & & & & & & $397-575$ & & \\
\hline \multirow{3}{*}{ Seeds } & 93 & 252 & 402 & 5 & 5 & & & \multirow{2}{*}{$\begin{array}{l}\text { Chadare et } \\
\text { al. } 2008\end{array}$} \\
\hline & $92-94$ & 30-395 & $282-696$ & $2-7$ & $2.6-7.3$ & & & \\
\hline & & 395 & 352 & 1.8 & 2.7 & & & $\begin{array}{l}\text { Rahul et al. } \\
2015[8]\end{array}$ \\
\hline
\end{tabular}

"The results are relatively low and the variability is due to drying methods (under the sun, under shade, cabinet dried)

Table 1: The nutrient composition (mean and range) of baobab leaves, pulps and seeds in dry matter basis

\begin{tabular}{|c|c|c|c|c|c|c|c|}
\hline Foodstuffs & $\begin{array}{c}\text { Moisture } \\
\%\end{array}$ & $\begin{array}{l}\text { Crude } \\
\text { fiber\% }\end{array}$ & $\begin{array}{c}\mathrm{Ca} \\
\mathrm{Mg} / 100 \mathrm{~g}\end{array}$ & $\begin{array}{c}\mathrm{Fe} \\
\mathrm{Mg} / 100 \mathrm{~g}\end{array}$ & $\begin{array}{c}\text { Vitamin C } \\
\mathrm{Mg} / 100 \mathrm{~g}\end{array}$ & $\begin{array}{l}\text { B-carotene } \\
\mu \mathrm{g} / 100 \mathrm{~g}\end{array}$ & $\begin{array}{l}\text { Retinol } \\
\mu \mathrm{g} / 100 \mathrm{~g}\end{array}$ \\
\hline \multirow{2}{*}{ Cereals } & 10.4 & 4 & 39.3 & 6.25 & & & \\
\hline & $9-12$ & $1.0-8.0$ & $3-92$ & $2-12$ & & & \\
\hline \multirow{2}{*}{ Legumes } & 10.4 & 6.4 & 149 & 11.9 & 16 & 95 & \\
\hline & $10-11$ & $5.7-6.8$ & $90-152$ & $6.7-18$ & & $60-30$ & \\
\hline \multirow{2}{*}{ Leafy vegs } & 90 & 1.1 & 89 & 1.4 & & 620 & \\
\hline & $83-93$ & $0.4-1.6$ & $47-32$ & $0.7-3.1$ & 54 & $100-430$ & \\
\hline \multirow{2}{*}{ Fruits } & 87 & 0.88 & 18 & 0,68 & 35 & 303 & \\
\hline & $80-93$ & $0.4-1.8$ & $3,0-38$ & $0.1-1.8$ & $16-74$ & $25-950$ & \\
\hline \multirow{2}{*}{ Meat } & 61 & & 10 & 4.2 & & & 2 \\
\hline & $46-77$ & & 9-11 & $3.6-4.8$ & & & \\
\hline Cows' milk & 85.2 & & 143 & & & & 95 \\
\hline Fish & 75 & & 32 & 1.7 & & & \\
\hline
\end{tabular}

\section{FAO. 2009 [28]}

Cereals $=$ sun dried whole grain - maize, rice, barley, teff, wheat

Legumes $=$ sun dried whole seed - beans, cowpea, garden peas

Leafy veg $=$ fresh vegetables - cabbage, kale, lettuce

Fruits $=$ fresh fruits - Tomato, apple, avocado, mango, lemon sweet, mandarin, orange, papaya, peach, pear, pine apple

Meat $=$ row - beef, mutton, pork

Fish $=$ filet, average all kinds

Table 2: Nutrient composition as-is (mean and range) of some common foodstuffs for comparison with baobab (Table 1)

Despite the problems of standardization in sample collection, preservation, preparation and analysis, valuable information about 
nutritional and therapeutic value of baobab is available. The calcium, iron and B-carotene content of the baobab leaves, calcium and vitamin $C$ of the pulp and magnesium of the seeds are outstanding. Baobab leaves contain 10-18 times more calcium than the common foodstuffs known as calcium-rich (e.g. milk, green-leafy-vegetables and pulses) (Table 2).

The pulp contains about $1 / 3$ the calcium in the leaves, 2 -times the concentration in milk and 3-4-times that in leafy vegetables. It is also rich in ascorbic acid (mean concentration $238 \mathrm{mg} / 100 \mathrm{~g}$ ) containing about six times more than common fruits. One of the important functions of vitamin $\mathrm{C}$ is the promotion of the bioavailability of dietary minerals through three distinct mechanisms [25]. First, it promotes acidic condition in the stomach and intestine maintaining conducive environment for iron absorption. Second, it chelates ferric iron $\left(\mathrm{Fe}^{+++}\right)$forming stable and soluble complex even at higher $\mathrm{pH}(>3)$. Third, it reduces ferric iron to ferrous iron, thereby preventing it from precipitation as ferric hydroxide. In addition, it is essential for the promotion and maintenance of health as described in the section dealing with therapeutic value of baobab, page 5. Baobab pulp contributes to these vital biological functions because of its unequalled content of vitamin C.

In cases where cereals dominate the staple diet, the absorption of $\mathrm{Fe}, \mathrm{Zn}$ and $\mathrm{Ca}$ decline because of relatively high content and activity of phytic acid [26]. Vitamin C, at levels of $30-50 \mathrm{mg} /$ day can overcome the negative impact of phytic acids and other inhibitor-molecules such as tannic- and oxalic acids [27]. Based on this information and the data given in Table 1, it is calculated that less than $20 \mathrm{~g}$ of baobab pulp can supply the desired level of vitamin C.

The staple diets in sub-Sahara Africa, which consist largely of cereals, roots and tubers, are low in calcium and at the same time high in phytic acid, oxalic acid and tannic acids that can hinder the bioavailability of calcium [29]. In line with this, children with bone deformities (rickets) due to calcium deficiency, but without overt vitamin D deficiency have been reported from Nigeria, the Gambia and South Africa [30]. In East Africa (Ethiopia, Kenia, Zimbabwe) the average daily diet with DDS (dietary diversity score) of more than four can only satisfy about $42 \%$ the minimum daily calcium requirement (800mg) [31]. In order to complement the diet and meet the daily requirement about $30 \mathrm{~g}$ baobab leaves, which are moderately rich in $\mathrm{Ca}(1582 \mathrm{mg} / 100 \mathrm{~g})$, or the combination of $25 \mathrm{mg}$ leaves and $20 \mathrm{~g}$ pulp (calcium density of $302 \mathrm{mg} / 100 \mathrm{~g}$ and vitamin C of $238 \mathrm{mg} / 100 \mathrm{~g}$ ) are recommended to increase both $\mathrm{Ca}$ intake and bioavailability. The leaves are additionally rich in $\beta$-carotene, the vitamin $\mathrm{A}$ precursor that can enhance calcium and iron absorption through the formation of soluble complexes and reversing the inhibitory effects of phytates and other polyphenols [32].

Iron deficiency anemia is the most prevalent health problem affecting about 2 billion people in the world [33,34]. It is characterized by the reduction of DNA replication, protein synthesis and cell formation (e.g. erythrocytes). As a result, iron deficiency contributes to the impairment of physical, cognitive and immune system development in childhood and to the reduction of work productivity by adults [34]. Nutritional iron deficiency arises when the iron concentration of the diet and/or its absorption from the intestine are suboptimal. Baobab leaves and fruit pulp have the potential of rectifying the problems.

Baobab leaves contain on the average $65 \mathrm{mg} F / 100 \mathrm{~g}$ sample, more than five times the level of iron present in the richest conventional foodstuffs (11.9mg Fe/100g legume) and more than $15 \mathrm{x}$ that in meat $(4.2 \mathrm{mg} / 100 \mathrm{~g}$ ) (Table 1 and 2). In East Africa, $30 \mathrm{~g}$ of baobab leaves that are meant to satisfy the daily requirement for calcium can as well more than satisfy the daily requirement for iron $(15 \mathrm{mg})$. If the concern is, however, to balance the daily iron requirement, then complementing the common daily diet with about $6 \mathrm{~g}$ of ground baobab leaves will be sufficient.

The pulp has moderate iron concentration that on the average is comparable to that in beef (about $4 \mathrm{mg} / 100$ ). However, the combination of its moderate iron and rich vitamin $\mathrm{C}$ content would enable the pulp to be a desirable complement of the daily diet in East Africa. Considering the average concentration of vitamin C in the pulp $(238 \mathrm{mg} / 100 \mathrm{~g})$, the average daily requirement by human beings ( $75 \mathrm{mg}$ ), and the content of average daily diet in East Africa (about $66 \mathrm{mg}$ ), the complementation of the diet with only $4-5 \mathrm{~g}$ pulp, will fulfill the daily requirement.

Baobab is additionally rich in magnesium and zinc. The magnesium content $(339 \mathrm{mg} / 100 \mathrm{~g}$ dry sample) of the leaves and that of the seeds $(402 \mathrm{mg} / 100 \mathrm{~g}$ dry sample) are 2.35 and 2.8 times that of pulses $(144 \mathrm{mg} / 100 \mathrm{~g})$, the foodstuffs commonly known as rich sources of magnesium. Conventional diets characterized by relatively high content of refined cereals are limited in $\mathrm{Mg}$ content (19-32 mg/100g) and high content of Mg-absorption inhibitors [35]. The phosphates in the cereals and most soft drinks bind magnesium and render it unavailable, while highly soluble carbohydrates increase the renal excretion [36].

For many years, the prevalence of magnesium deficiency and its importance in structural, biochemical and physiological functions of the body did not get as much attention as that of iron, iodine and vitamin A, probably due to the lack of specific symptoms to detect its deficiency and the unwarranted conviction that common diets contain adequate magnesium [37]. However, recent observation on the treatment effect of magnesium, which resulted in some relief from pain, heart problems and its depleting effect, inflicted the need for revision of old concepts. Accordingly, balance studies about the adequacy of magnesium even in some developed regions came up with unexpectedly high negative results. Average daily magnesium intake in the US, France, Israel and South Africa proved to be only $50 \%, 79 \%, 59 \%$, and $61 \%$ of the recommended daily intake ( $420 \mathrm{mg} /$ day) [33]. Depletion of soil magnesium due to intensive monoculture agricultural, and the processing and refining of foodstuffs, as well as softening of drinking water to increase its household cleaning quality are some of the causes of the decline in the supply and intake of magnesium [38,39]. 
Magnesium is essential for a wide range of metabolic reactions because of its activities as the co-factor of at least 300 enzymes that are involved in energy, protein and DNAs metabolisms and its involvement in bone formation and function [37,40]. Magnesium deficiency can slow down these functions and cause health problems, which are most often asymptomatic. However, muscular chronic weakness, cramps, fatigue, forgetfulness and cardiac arrhythmia can be related to magnesium deficiency [40].

The average amount of food available for consumption in Africa, albeit the differences between countries, is 1508g/cap/day or $2771 \mathrm{kcal} / \mathrm{cap} /$ day [28,31]. A balance study depicted that this diet, which is prepared from variable quantities of processed cereals, roots, tubers, pulses, vegetables nuts, meat, milk and its products, fat and sugar supplies $325 \mathrm{mg}$ magnesium, which is 80 $95 \mathrm{mg}$ short of the recommended level of daily intake. Some $25 \mathrm{~g}$ of each of baobab leaves or seeds can rectify the deficiency. A combination of $15 \mathrm{~g}$ seed and $11 \mathrm{~g}$ pulp can form an optimal alternative for the reason that the ascorbic acid of the pulp at the same time promotes the bioavailability of magnesium as well as that of calcium, iron and zinc.

The leaves and seeds of baobab have better concentration of zinc, ( 4 and $5 \mathrm{mg} / 100 \mathrm{~g}$ respectively), than the commonly known rich sources including legumes $(2.4 \mathrm{mg} / 100 \mathrm{~g})$, beef $(1.6 \mathrm{mg} / 100 \mathrm{~g})$ and some fish sorts $(2.4 \mathrm{mg} / 100 \mathrm{~g})$ [41]. In addition, the extra ordinarily rich content of ascorbic acid in the pulp can promote the bioavailability of zinc to meet the demand for metabolic processes [26,42]. The combination of the three biological parts of baobab can form a worthy complement to the daily diets in East Africa and other zinc deficient regions like South Asia. They would not only provide twice more zinc than the richest common foodstuffs but they could also improve its bioavailability.

There are instances when the test of mineral adequacy based on balance studies by comparing requirement and intake seem to require some revision. A balanced diet adequate in all nutrients including zinc was not able to support the desired growth; but the enrichment of the diet with zinc supplement promoted optimal growth [43]. It appears that more zinc than required improved the performance, but in reality, it could also be a problem of the bioavailability of the zinc in the original situation. This suggests that absorption promoters like vitamin $\mathrm{C}$ could also support growth when the zinc demand and intake are at equilibrium. In this case, an arbitrary supply of about $20 \mathrm{~g}$ pulp with $56 \mathrm{mg}$ of vitamin $\mathrm{C}$ could bring about the desired effect.

Similar to magnesium, zinc is an integral component of about 300 anabolic or catabolic enzymes that catalyze the synthesis and/ or the degradation of all major metabolites [45]. It is involved in DNAs and proteins synthesis, the stabilization of their structure, integration of sub-cellular organelles, transportation of metabolites such as iron, and in immune system functions [45]. Any negative influence to these functions arising from the consumption of diets low in zinc and/or vitamin C and high in cereals that are rich in phytate and dietary fiber can cause stunting in children and adolescents, dermatitis, poor wound healing, suppression of immunity, neurophysiological impairment, and pregnancy complication [43].

Nearly half of the world population is at risk of zinc deficiency because of inadequate zinc intake and low bioavailability [44]. The effect is more prevalent in Africa and South Asia not only because of relatively lower intake of zinc (about 9mg/day) as compared to that of North America and West Europe (12mg/day) but also due to lower bioavailability as a result of high phytic acid content of the diets (phytate:zinc molar ratio 26:13). The phytate: zinc molar ratio at the levels of $\leq 15$ do not result in negative growth performance but those higher than 15 , and particularly those in the range of $\geq 20$ slow down body growth [42].

\section{Therapeutic Value}

Baobab (Adansonia digitata L.) has a long history of nutritional and ethno medical values in Africa. In ancient Egypt, baobab was used to treat fever and dysentery while in sub-Sahara Africa the different botanical parts of baobab are applied to treat diarrhea, malaria and microbial infections [46,47]. Baobab can prevent hypertension, chronic heart diseases, stroke, diabetes and Alzheimer's disease by combating oxidative stress $[48,50]$. The pathway of oxidative stress, health disturbances and the involvement of baobab in the antioxidant activity and the prevention of diseases is shown using Figure 1 and 2.

Free radicals, particularly reactive oxygen species (ROS) are predominantly the products of biochemical reactions, but some can result from cigarette-smoke, radiation, air pollution and medication [50,51]. In normal conditions, naturally occurring antioxidants like superoxide dismutase, catalases, glutathione peroxidases and vitamins $\mathrm{C}, \mathrm{A}, \mathrm{E}$ counter act the oxidants and conduct regulatory functions related to immune defense, antibacterial activity, and vascular tone [51]. In case of imbalance between ROS and natural antioxidants, external antioxidants originating from food sources like baobab can stabilize the superfluous ROS, and prevent oxidative damage to body lipids, DNAs and proteins, thus inhibiting diseases like atherosclerosis, hypertension, cardiovascular diseases, neurodegeneration and cancer [50,52].

Excess ROS can additionally damage tissues and activate phagocytes that cause the release of transitional metal ions, furthering ROS generation and worsening the injuries. Likewise, mitochondrial damage increases the release of intermembrane proteins such as cytochromes to cytosol, reduces ATP-synthesis, slows down metabolic processes, (TCA cycle, fatty acid oxidation, amino acid metabolism, urea cycle) and activates the cells apoptosis/necrosis (Figure 1) [49].

Baobab is an essential natural resource with high antioxidant potential because of its richness in polyphenols mainly flavonoids and its panacea property [59]. Distinctive chemical structures of flavonoids including the ortho-dihydroxy arrangement in ring B (Figure 2) are associated with antioxidant activities. The hydroxyl group donates its hydrogen atom to a radical molecule in 
two steps (top left, bottom left, Figure 2), thereby stabilizing it and consequently generating a relatively stable flavonoid phenoxyl radical, which in the subsequent reaction give stable quinone structure. The B-ring hydroxyl is the most active scavenger of both oxygen and nitrogen centered free radicals. Hydroxyl groups of this nucleus donate hydrogen and an electron to hydroxyl, peroxyl and peroxynitrite radicals, stabilizing them and giving rise to relatively stable flavonoid radicals. Among the flavonoid derivatives, quercetin and anthocyanins expresses higher antioxidant capacity [53].

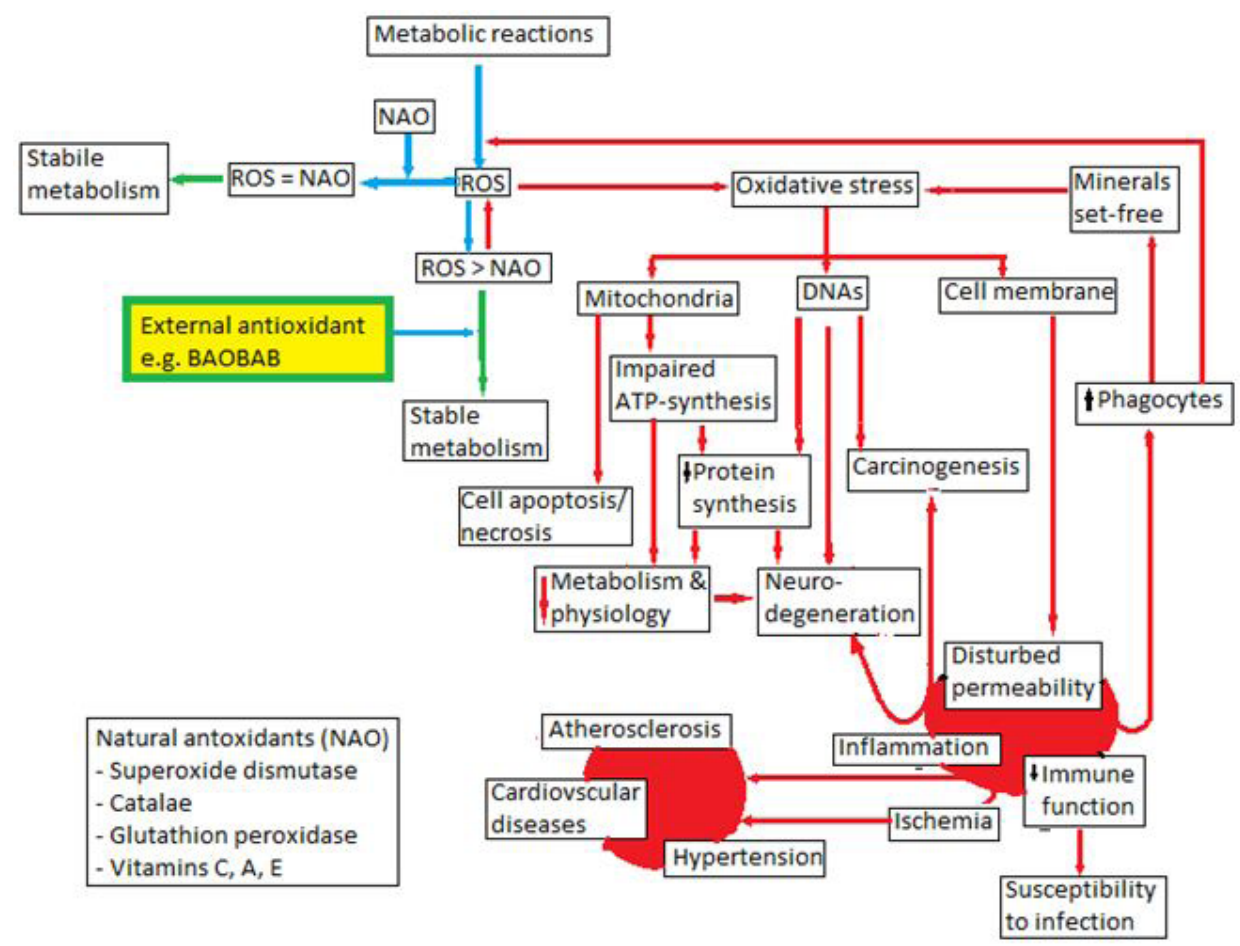

Figure 1: The role of baobab in hinderingthe path of oxidative stress and subsequenthealth problems<smiles>Cc1ccc(O)c(O)c1</smiles>

$\mathrm{Fl}-\mathrm{OH}$<smiles>Cc1ccc(O)c([O-])c1</smiles>

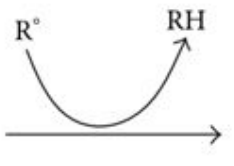

(a)<smiles>Cc1ccc(O)c([O-])c1</smiles>

$\mathrm{F} 1-\mathrm{O}^{\circ}$<smiles></smiles>

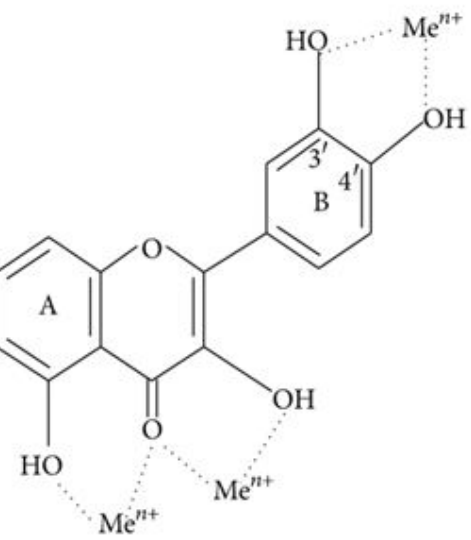

(b)

(a) Flavonoids Fl-OH scavenge ROS $\left(\mathrm{R}^{\circ}\right)$ and neutralize it to RH by two steps reaction;

(b) Binding sites for trace minerals where $\mathrm{Me}^{\mathrm{n}+}$ indicates metal ions

Figure 2: Antioxidant actions of flavonoids

Increasing fruit and vegetable consumption to $600 \mathrm{~g} /$ day can reduce the total burden of ROS and associated diseases because of their richness in antioxidant molecules among which polyphenols are predominant [55]. Total phenols content of tropical fruits and vegetables ranges between 11.7 and $978.6 \mathrm{mg} / 100 \mathrm{~g}$ [60]. Baobab outstands most of the commonly known fruits and vegetables in phenolic content $(1085 \mathrm{mg} / 100 \mathrm{~g}$ pulp) and shows better potential in preventing chronic diseases arising from oxidative stress [56]. It specially contains ample anthocyanins, the flavonoids that are effective both in scavenging reactive oxygen and in inhibiting lipoprotein oxidation and platelet aggregation [56].

Baobab is a better source of flavonoids than fruits and vegetables and have versatile health benefits associated with the inhibition of oxidative stress, and the induction of anti-inflammatory, anti-cancer and antiviral activities [50]. Likewise, it can prevent cardiovascular diseases [55]. The fruit pulp is used to treat infections because of its relatively high vitamin $\mathrm{C}$ and antioxidant content [58]. Baobab's anti-oxidant and anti-inflammatory properties do not only make it essential for medical use but also for use in food technology. 
A comparison of the integral antioxidant capacity (IAC) of baobab and selected common food resources indicated that the former outstrips by high range (Table 3). Similarly, Vertuani S et al. (2002) stated that the IAC of baobab pulp extract is 10 times that of orange [58]. The most impressive IAC $(1617.3 \mu \mathrm{mol} / \mathrm{g})$ is, however, that of baobab red fiber, which is 66 times that of orange $(24.3 \mu \mathrm{mol} / \mathrm{g})[61]$.

\begin{tabular}{|c|c|c|c|}
\hline Products & $\begin{array}{c}\text { Ascorbic acid } \\
\text { equivalent antioxi- } \\
\text { dant capacity }\end{array}$ & $\begin{array}{c}\text { Torlox equiva- } \\
\text { lent antioxidant } \\
\text { capacity }\end{array}$ & $\begin{array}{c}\text { Integrated anti- } \\
\text { oxidant capacity } \\
\text { (IAC) } \mu \mathrm{mol} / \mathrm{g}\end{array}$ \\
\hline Baobab pulp & $75.0 \pm 0.005$ & $25.0 \pm 0.0015$ & 240.5 \\
\hline $\begin{array}{c}\text { Baobab } \\
\text { leaves }\end{array}$ & $23.0 \pm 0.002$ & $24.5 \pm 0.003$ & 89.0 \\
\hline $\begin{array}{c}\text { Baobab } \\
\text { seeds }\end{array}$ & $16.0 \pm 0.007$ & $6.5 \pm 0.0004$ & 51.4 \\
\hline Orange fruit & $17.0 \pm 0.015$ & $0.29 \pm 0.0015$ & 24.3 \\
\hline $\begin{array}{c}\text { Strawberry } \\
\text { fruit }\end{array}$ & $1.72 \pm 0.006$ & $0.36 \pm 0.006$ & 5.3 \\
\hline
\end{tabular}

Recent evidences indicate that the aqueous extract of baobab-bark, which contains polyphenols including anthocyanins, proved an anti-sickling activity [52]. Baobab can stabilize sickled-blood-cells-membrane, reduce methemoglobin to hemoglobin and produce anti-sickling effect [52]. Its anti-inflammatory, anti-cancer and antiviral activity are well-documented [46]. Crude ethanoic and aqueous extracts of the stem and root-barks, which contain bioactive constituents like tannins, terpenoids, saponin and other polyphenols, resulted in significant antibacterial activity [47]. In an experiment with broilers, that are supplied with a diet containing decorticated extracted roasted baobab seed meal (DERBSM) at limited extent (about 5\% $\pm 2.5 \%$ ), the extract induced anti-oxidative property, which reduced the oxidative spoilage to meat and promoted body weight gain and food efficiency [57].

\section{Conclusion}

The botanical parts of baobab prove different levels of unequaled nutrient content compared to legumes, vegetables and fruits. The leaves are the richest in calcium, iron and $B$-carotene content, while the pulp and seeds are outstanding in vitamin $\mathrm{C}$ and magnesium respectively. There is, however, a wide range of variability of nutrient content even within similar botanical parts. The standardization of samples according to botanical characteristics (phenotype, age of tree...), location of growth (site, topography), edaphic characteristics (soil type, texture, chemistry...), climate (rainfall, temperature) cultural practices (plant husbandry, harvesting procedures and season...), dehydration, storage, shelf life, and methods of lab-analysis, can minimize experimental error and differences, making generalization and interpretation of results easy and reliable.

It is possible to rationalize the therapeutic value of baobab using the levels of its nutrient composition, antioxidant activity in the pathway of oxidative stress and health impacts. However, biological and/or biochemical evidences that confirm the effects and standardize the level of intake are hardly known. In this respect, a large area of research remains open.

\section{References}

1. Bamali Z, Mohammed AS, Ghazali HM, Karim R (2014) Baobab Tree (Adansonia digitata L) Parts: Nutrition, Application in Food Uses in Ethno-medicine-A Review. Ann Nutr Disord \& Ther 1: 1011-20.

2. Sidibe M, Williams JT (2002) Fruits for the Future: Baobab (Adansonia digitata L). International Centre for Under-utilized Crops, Southampton, UK.

3. Van Wyk BE (2011) The potential of South African plants in the development of new food and beverage products. South Afri J Botany 77: 857-68.

4. Kabore D, Swadogo-Lingani H, Diawara B, Compaoré CS, Dicko HM, et al. (2011) A review of baobab (Adansonia digitata) products: Effect of processing techniques, medicinal properties and uses. Afric J Food Sci 5: 833-44.

5. Al-Qarawi A, Al-Damegh M, El-Mougy S (2008) Hepatoprotective influence of Adansonia digitata pulp. J herbs spices med plants 10:1-6.

6. Gebauer J, El-Siddig K, Ebert G (2002) Baobab (Adansonia digitata L): A review on the multipurpose tree with promising future in Sudan. Die Gartenbauwissenschaft 67:155-160.

7. Nordeide MB, Hatloy A, Folling M, Lied E, Oshaug A (2009) Nutrient composition and nutritional importance of green leaves and wild food resources in an agricultural district in Koutiala, in South Mali. Int J Food Sci Nutr 47: 455-68.

8. Rahul J, Jain MK, Singh SP, Kamal RK, Naz A, et al. (2015) Adansonia Digitata L. (baobab): a review of traditional information and taxonomic description. Asian Pacific J Tropical Biomedi 5: 79-84.

9. Addy EO, Eteshola E (1984) Nutritive value of a mixture of tigernut tubers (Cyperusesculentus L) and baobab seed (Adansonia digitate L.) J Sci Food Agric 35: 437-40.

10. Chadare FJ, Linnemann AR, Hounhouigan JD, Nout MJR, Van Boekel MAJS (2008) Baobab Food Products: A Review on their Composition and Nutritional Value. Criti Rev Food Sci Nutr 49: 254-74.

11. Assogbajo AE, Sinsin B, Codjia C, Van Damme P (2005) Ecological Diversity and Pulp, Seed and Kernel Production of the Baobab (Adansonia digitata) in Benin. Belg Journ Bot 138: 47-56. 
12. EC (2008) Baobab dried fruit pulp. EC No. 72. EU Commission Decision 2008/525/EC, UK.

13. FDA (2009) Agency Response Letter GRAS Notice No. GRN 000273. USFDA, UK.

14. Parkouda C, Sanou H, Tougiani A, Korbo A, Nielson DS, et al. (2012) Variability of Baobab (Adansonia digitata L) fruits' physical characteristics and nutrient content in the West Africa Sahel. Agroforest Syst 85: 455-63.

15. Rahul J, Jain MK, Singh SP, Kamal RK, Naz A, et al. (2015) Adansonia Digitata L. (baobab): a review of traditional information and taxonomic description. Asian Pacific J Tropical Biomedi 5: 79-84.

16. Osman MA (2004) Chemical and Nutrient Analysis of Baobab (Adansonia digitata) Fruit and Seed Protein Solubility. Plant Foods Hum Nutr 59: 29-33.

17. Gebauer J, El-Siddig K, Ebert G (2002) Baobab (Adansonia digitata L): A review on the multipurpose tree with promising future in Sudan. Die Gartenbauwissenschaft 67: 155-60

18. Gebauer J, Adam YO, Sanchez AC, Darr D, Habte TY, et al. (2016) Africa's wooden elephant: the baobab tree (Adansonia digitata L.) in Sudan and Kenya: a review. Genet Resour Crop Evol 63: 377-99.

19. Dhillon SS, Gustad G (2004) Local management practices influence the variability of the baobab (Adansonia digitata L) in different land use types Cinzana, Mali. Agric Ecosyst Environ. 101: 85-103.

20. PTA (2008) Baobab (Adansonia digitata) Fruit Pulp Powder Production Capacity and Sustainability in South Africa: Briefings Document Phyto-Trade Africa. London, South Africa.

21. Ogechukwu O (2015) Comparison of Atomic Absorption and Atomic Emission Spectroscopic methods for Effluent Analysis.

22. Abioye VF, Adejuyitan JA, Idowu CF (2014) Effects of different drying methods on the nutritional and quality attributes of baobab leaves (Adansonia digitata). Agric Biol J N Am 5: 104-108.

23. LFR (2009) Nutritional Evaluation of Baobab Dried Fruit Pulp and Its potential Health benefits. Semantic Scholar.

24. Cissé I, Didier M, Max R, Pascal D, Benjamin Y, et al. (2013) Biochemical and nutritional properties of baobab pulp from endemic species of Madagascar and the African mainland. Afr J Agri Res 8: 6046-54.

25. Teucher B, Olivares M, Cori H (2004) Enhancers of iron absorption: Ascorbic acid and other organic acids. Int J Vitam Nutr Res 74: 403-19.

26. Lopez HW, Leenhard F, Coudray C, Remesy C (2002) Minerals and phytic acid interactions: is it a real problem for human nutrition? Int J Food Sci Technol 37: 727-39.

27. Siegenberg D, Baynes RD, Bothwell TH, Macfarlane BJ, Car NG, et al. (1991) Ascorbic acid prevents the dose dependent inhibitory effect of polyphenols and phytates on non-hem iron absorption. Am J Clin Nutr 53: 537-41.

28. FAO (2009) Food Composition Table for Use in Africa.

29. Prentice A, Schoenmakers I, Jones KS, Jarjou LMA, Goldberg GR (2009) Vitamin D Deficiency and its Health Consequences in Africa. Clin Rev Bone Miner Meta 7: 94-106.

30. Swaminathan R (2003) Magnesium Metabolism and its Disorders. Clin Biochem Rev. 24: 47-66

31. Habte TY, Krawinkel M (2014) Nutritional Adequacy and Natural Means of Rectifying Nutrient Deficiency Problems in Africa. Int J AgriSci.

32. Layrisse M, Garcia-Casal MN, Solano L, Baron MA, Arguello F, et al. (2000) New property of vitamin A and beta-carotene on human iron absorption: Effect on phytate and polyphenols as inhibitors of iron absorption. Arch Latinoam Nutr 50: 243-48.

33. Lieberman S, Bruning N (2007) The Real Vitamin and Mineral Book. New York.

34. WHO (2017) Micronutrient deficiency: Iron deficiency anemia, Geneva, Switzerland.

35. Black R (2003) Micronutrient deficiency an underlying cause of morbidity and mortality. Bull World Health Organ 81: 79.

36. Dean C (2003) The miracle of magnesium. (1st Ed.). The Random House Publishing Group, USA, Pp34-36.

37. Flink EB (1980) Nutritional aspects of magnesium metabolism. West J Med 133: 304-12.

38. Ewel JJ, Mazzarino MJ, Berish CW (1991) Tropical Soil Fertility Changes under Monocultures and Successional Communities of Different Structure. Ecol Appl 1: 289-302.

39. Gruenwald J (2009) Novel botanical ingredients for beverages. Clin Dermatol 27: 210-16.

40. Jahnen-Dechent W, Ketteler M (2012) Magnesium basic. Clin Kidney J 1: 3-14.

41. Tidemann-Anderson I, Acham H, Maage A, Malde M K (2011) Iron and zinc content of selected foods in the diet of schoolchildren in Kumi district, east Uganda: a cross-sectional study. Nutr J 10: 81-93.

42. Morris ER, Ellis R (1981) Phytate-Zinc Molar Ratio of Breakfast Cereals and Bioavailability of Zinc to Rats. Cereal Chem 58: 363-6.

43. Sandstead HH (1991) Zinc Deficiency: A Public Health Problem? Am J DIS Child 145: 853-9.

44. Brown KH, Wuehler SE, Pearson JM (2001) The importance of zinc in human nutrition and estimation of the global prevalence of zinc deficiency. Food Nutr Bul 22: 113-25.

45. Vallee BL, Auld DS (1990) Zinc Coordination, Function, and Structure of Zinc Enzymes and other Proteins. Biochemistry 29: 5647-59.

46. Kamattou GPP, Vermaak I, Viljoen AM (2011) An updated review of Adansonia digitata: A commercially important African tree. South Afri J Botany 77: 908-19.

47. Masola SN, Mosha RD, Wambura PN (2009) Assessment of antimicrobial activity of crude extracts of stem and root barks from Adansonia digitata (African baobab). Afri J Biotechnol 8: 5076-83.

48. Kumar S, Pandey A K (2013) Chemistry and biological activities of flavonoids: An overview. The Sci World J 2013: 1-16.

49. Murphy M P (2009) How mitochondria produces reactive oxygen species. Biochem J 417: 1-13.

50. Pham-Huy LA, Hau H, Pham-Huy C (2008) Free Radicals, Antioxidants in Disease and Health. Int J Biomed Sci 4: 89-69.

51. Alfada AA, Sallama RM (2012) Reactive Oxygen Species in Health and Disease. J Biomed Biotech 2012: 14-21.

52. Mpiana PT, Miskabu FS, Tshibangu DST, Ngbohia KN, Mwanangombo (2014) Antisickling Activity and Membrane Stabilizing Effect of Anthocyanins Extracts from Adansonia digitata L. Barks on Sickle Blood Cells. Int Blood Res Rev 2:198-212.

53. Moalin M, Strijdonck GPF, Beckers M, Hagemen G, Borm P, et al. (2011) A planar conformation and hydroxyl groups in the B and C rings play a pivotal role in the antioxidant capacity of quercetin and quercetin-derivatives. Molecules 16: 9636-50. 
54. Yazzi D, Van der Jagt DJ, Pastiszyn A, Okolo A, Glwe RH (1994) The amono acids and mineral content of baobab (Adansonia digitata L.) leaves. J Food Compost Anal 7: 189-93

55. Lako J, Trenerry VC, Wahlqvist M, Wattanapenpaiboon N, Sotheeswaran, et al. (2007) Phytochemical flavons, carotenoids and the antioxidant properties of a wide selection of Fijian fruits, vegetables and other readily available foods. Food Chem 101: 1727-14.

56. Kong JM, Chia LS, Goh NK, Chia TF, Brouiland P (2003) Analysis and biological activities of anthocyanins. Phytochemistry 64: $923-33$.

57. Sola-Ojo FE, Adeyemi KD, Toye AA, Bolu SA, Fayeye TR, et al. (2013) Performance, Carcass Profile and Oxidative Stability of Broiler chickens fed Processed Baobab Seed Meal. Bull Env Pharmacol Life Sci 2: 94-9.

58. Vertuani S, Braccioli E, Buzzoni V, Manfredini S (2002) Antioxidant capacity of Adansonia digitata fruit pulp and leaves. ACTA Phytotherapeutica 2: 2-7.

59. Lobo V, Patil A, Phatak A, Chandra N (2010) Free radicals, antioxidants, and functional foods: Impact on human health. Pharmacogn Rev. 4: 118-26.

60. Ellong EN, Billard C, Adenet S, Rochefort K (2015) Polyphenols, Carotene, Vitamin C Content in Tropical Fruits and vegetables and Impact of Processing methods. Food and Nutr Sci 6: 299-313.

61. Besco E, Braccioli E, Verluani S, Ziosi P, Brazzo F, et al. (2007) The use of photochemiluminescence for the measurement of the integral antioxidant capacity of baobab products. Food Chemistry $102: 1352-6$

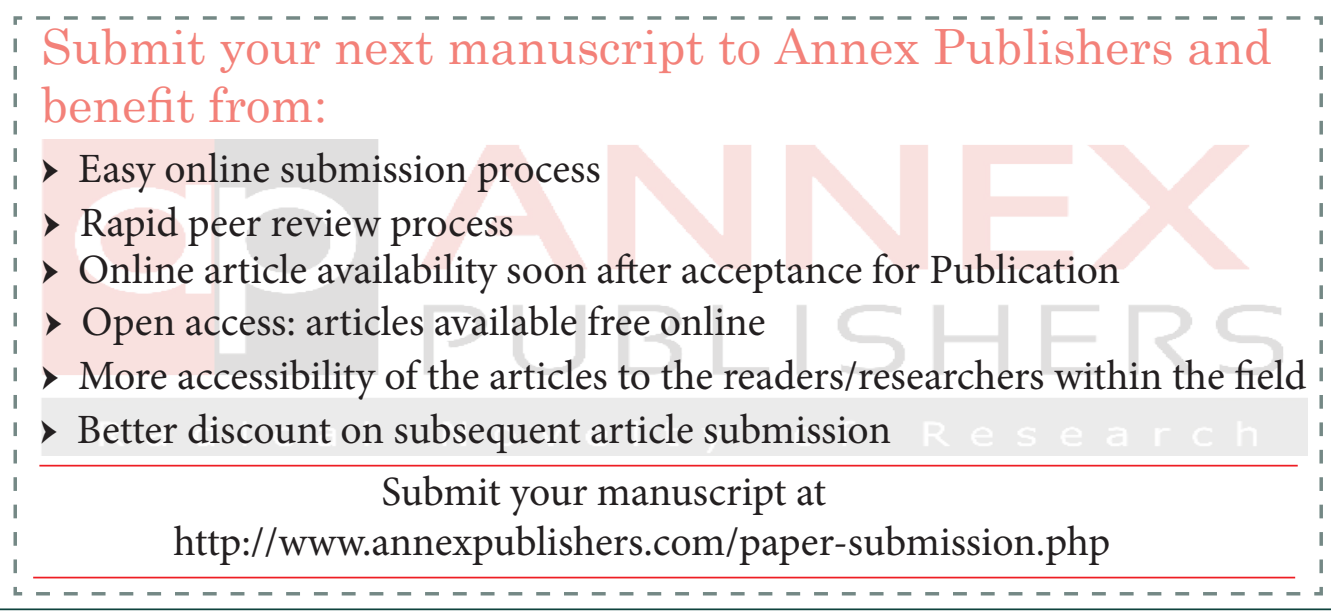

